\title{
Revitalization of Human Resources in Improving Public Bureaucracy Performance
}

\author{
Hasan Ubaidillah \\ Fakultas Ekonomi dan Bisnis \\ Universitas Muhammadiyah Sidoarjo \\ Sidoarjo, Indonesia \\ ubaid@umsida.ac.id
}

\begin{abstract}
- a number of negatives are addressed to the public bureaucracy which is indicated, among other things, as: sluggish, red tape, rigid, efficient, arrogant, and so on. This research aims to improve the public bureaucracy in Sidoarjo regency through: 1) The development of bureaucratic resources (human) is directed to the realization of merit system and openness since the recruitment process until mutation and promotion with the support of training system capable of giving birth to professional workers 2) Building organizational culture towards efficiency, effectiveness, transparency, professionalism, and customerorientation initiated by top management (strategic apex), 3) Organizational structure must ensure flexibility and speed in decision-making by delegating adequate authority to middle- The executor (operating core). The research methodology used in this research is qualitative. Data obtained through direct observation and interview with key informant in depth (in dept interview). To determine the key informants the researchers used stratified random sampling. The result of this research is recruitment has led to merit system and transparency, career development not yet fully oriented to work achievement, education institution. The reality of organizational culture shows that there are nonconducive cultures in some employees. The culture or organizational culture has a strong influence on the effort to build a public bureaucracy.
\end{abstract}

Keywords: good governance; professionalism; accountability; human resources; public bureaucracy

\section{INTRODUCTION}

The process of national development that took place today is undergoing a shift from authoritarian system frame to the democratic system. This led to the Organization of the Government into a sharp spotlight, especially in the aspect of transparency, accountability, efficiency and effectiveness. In line with this, the development and growth of the community that dynamically coupled with an increase in the standard of living and community education coupled with the growing advances in the field of technology and informatics makes an increase the process of empowering the community. Therefore the Ministry of public sector bureaucracy is also expected to follow the changes that occur in a fast and dynamic, as occurred in the community.

In this context, the application of the principles of good governance in the management of the Government became a major assertion, because the community start critical in monitoring and evaluating the benefits and value of services obtained from institutions the Government. The onset of the economic crisis in Indonesia is a valuable experience that provides learning over the conduct of the Government that are not being managed and well-regulated. As a result there arose a variety of problems such as corruption, collusion and nepotism (KKN) eradicated a difficult, difficult law enforcement problems walking, monopoly in economic activities, as well as the quality of service to the community that is deteriorating.

Addressing the phenomena of bureaucracy, then the fundamental changes need to be made against the ' Anatomy ' of public bureaucracy in order to materialize the bureaucracy that is able to adapt to the changing strategic environment. Especially in the era of regional autonomy, which requires that the independence of the Government to manage and take care of his household alone amid the global competition and increasing public awareness of the role of public bureaucracy.

Sidoarjo regency government it was time for realignment of his role during this time became a public bureaucracy has accountability, innovative and responsive, professional and spirited entrepreneur. The old patterns in a bureaucratic culture, institutional structures, leadership, human resource management and so forth should be reoriented towards the 
establishment of a public bureaucracy is adaptive to changes in the strategic environment that goes fast and globalizing.

Thus, this study is proposed to describe and analyze the performance of human resources in the public bureaucracy in Sidoarjo regency. Further, it identifies the renewal of government bureaucratic Sidoarjo in the face of environmental changes especially the policy of autonomous region as well as the constraints and opportunities that enclosing them. The last, this elaborates on findings in the research to recommend suggestions that can be applied in establishing the public bureaucracy in Sidoarjo regency.

\section{LITERATURE REVIEW}

Research was based on an attempt to make a change of the government bureaucracy through Sidoarjo approach of New Public Management.

\section{A. Models of NPM (New Public Management}

Is a model developed in an attempt to improve the performance of the bureaucracy with the traditional model, felt less able to respond to the changing environment and meet the expectations of the community will promote managerial approach with services. NPM focuses on improvements to the bureaucracy from within your organization (inside the organization) by making the necessary changes. [2]

The objective of the NPM approach include: first, prefer the results the purpose and responsibilities of personal Manager; Second, pay more attention to the establishment of the Organization, personnel, and workers and a more flexible; third, make objective of organizations and personnel are clear and easily measured by determining the charge indicators will; Fourth, more senior staff had a political commitment on the Government, not partisan and not neutral; Fifth, more government functions to the facilitators of executing on; Lastly, on the function of Government is reduced by the privatized. [2]

\section{B. Renewal of Culture}

Culture is a very strong on more influenced in an organization including public bureaucracy. Understanding basic together in an organization and are used as a tool to solve problems and make adjustments to external factors and internal factors, and integration have been proved the truth, then lowered to the members of the new organization as a way to solve the problem at hand.[1]

\section{Renewal Of The Structure}

The organizational structure basically determines how the job task is divided, grouped and formally coordinated. And the bureaucratic structure is characterized by tasks very routine operations achieved through specialization, rules and settings that are very formal, tasks are grouped into functional departments, centralized authority, the range the narrow control and decision-making which followed the chain of command. [3]

Based on the above opinion, the organizational structure is one of the components that need to be updated in the form of public bureaucracy through NPM approach. The question is how the structure of the bureaucracy can better allow the bureaucrats can develop innovation and more responsip to changes.

\section{The Renewal of Development Resources (Human) Bureaucrats}

Resource development bureaucrats is another component that needs to be updated in the form of public bureaucracy. Renewal here include resource requirements planning bureaucrat (human), the system of recruitment, placement, compensation, evaluate performance against bureaucrats and performance improvement through training as well as creating an environment a conducive work. [4]

The bureaucracy of the public must have a consistent and clear planning in resource management bureaucrats. Planning must be tailored the needs of achievement of the objectives that have been poured in the vision and mission of the Organization, which is implemented in the further analysis of the terms (job analysis).

\section{METHOD}

Research methodology used in writing this is qualitative research with a focus on the analysis of the bureaucracy with the object of research of bureaucracy in Sidoarjo, as one of the districts in the territory of the province of East Java. The required data, obtained through direct observation and interviewing key informants in depth (in-dept interview) in the area of research with the stick to the guideline of the interview. In this research that became respondents is people who are thought to have information (key informant) that are needed in the area of research. To determine the author's key informant, using stratified random sampling.

\section{RESULT}

A. The reality of Bureaucracy in Sidoarjo Regency

1. Culture

From the results of observation and interview the upfront identification of reality as depicted culture that indicates things are as follows:

- Two-way communication has not yet woken up properly, subordinates generally don't have the critical attitude toward superiors. 
- In the framework of the public service is not fully oriented towards the customer.

- Discipline and work culture is not yet optimal.

Although some of the pictures show the optimal values of the NPM has not been in the organizational culture in Sidoarjo, however the renewal of culture in the implementation of NPM values (such as: efficiency, effectiveness, transparency, and professionalism), has also begun to appear to be developed in implementing the tasks of the Government.

Another important aspect in the bureaucratic culture is how to grow a critical attitude and courage make corrections whenever going misappropriation and misuse of power. In a society that still leaves paternalism culture and attitude of "ewuh pakewuh" necessary steps to foster a renewal of courage in doing social control.

\section{Structure}

The structure of the Organization to be a part that is important in any organization including public bureaucracy because its function in determining how job duties are divided and grouped formally. In addition, the structure also describe the chain of command and the line of authority from the top of the organization up to the lowest Echelon so that it becomes clear who is responsible to whom. By looking at the structure can also be helpful to estimate how large the resources (Human Resources, equipment, and cost) required to move the organization.

In the affairs of governance work has not yet been set but the implementation of routine tasks and development works as usual due to the delegation of authority is quite flexible. For example, for a few months later the Governors are not available because of the following activities, but the tasks he carried out by Vice Regent. On the lower level, although not yet fully materialized yet no attempt to foster initiative and creativity to the managing staff in carrying out the policy of the mechanism and procedures.

\section{Resource Development Bureaucrats (Human)}

Employee recruitment process on the government district of Sidoarjo still based on old provisions where the authorities set the formation is determined by the Centre and yet grounded by an analysis of the needs of employees.

Provider education and training officer at Sidoarjo status the agency has full authority and equipped with infrastructure and means of work in education and training [5]. One of the important part that must be maintained by the Agency's Training is the development of module-oriented interests of riel according the demands of development. If the observed training followed by the employees in terms of the number is indeed quite big, but if viewed from the field training that followed seems to be more based on two main objectives, namely:

- Participants generally oriented to the field of structural training in the framework of the formal eligibility to occupy specific offices.

- Participants generally functional training in dasari by motivation to meet formal persyarakatan in order to fill the Organization's projects such as the KMP (Project Management Course), Treasurer, AKD (Financial Administration Area).

Haven't looked a strong willingness to establish or improve the functional technical staffs who have particular expertise in realizing the Organization lean and rich functions such as: archivist, librarian, researcher, policy analyst, and so on.

B. Analysis of NPM on the bureaucracy in Sidoarjo Regency

1. Renewal of Culture.

The theory of cultural reform is a key factor in the process of change in many organizations, especially in local government [6].

Throughout the efforts made by the County Government in building the culture of the Organization as outlined above, if observed from the cultural principles of NPM is indeed still not adequate. This is mainly due to the formation of organizational culture is not easy and can be done in a short time. Therefore, the government of Sidoarjo regency still need further renewal efforts to form the desired organizational culture in harmony with the values of the NPM is indicated by the following things; a). The realization of the values of efficiency and effectiveness in conducting public service practice, b). The formation of a professional and innovative apparatus in carrying out its tasks. c). The value of transparency, d). Harmonious mechanism of two-way communication and e). Spirit of harmonious togetherness.

\section{Renewal of The Structure}

If seen from the viewpoint of NPM, Sidoarjo regency government organizational structure is desired must meet the following criteria; a) The nature of the short chain of command, b) Lean (lean and mean), has a flexibilkitas which gives the ability to move quickly, as well as rich functions, c) Low formalization with a specialization that is not rigid and decentralized authority adequately in decision-making, would be very formalization the fetter of creativity and innovation.

\section{The renewal of development resources (human) \\ Bureaucrats.}

Seen from the viewpoint of NPM and dotted decline of indicators outlined in the previous chapter resource development then bureaucrats (humans) which must be 
embodied are: a) Recruitment officers are open by charging the formation based on the analysis of the needs of employees as well as by referring to the description of the position and specifications of the work, b) Coaching career Officers from the recruitment, placement and promotion with a mutation to based on a merit system, c) education and training employees should be directed to the preparation of staffs of professionals who are not only capable in the orientation of the present but also obtain reliable has the potential to anticipate future demands, and d) the placement of employees is based on the the principle of the right man on the right place or the right man on the right job so that every employee can actualize themselves optimally for the interests of the organization.

\section{CONCLUSION}

Recruitment has led to the merit system and transparency. Career coaching is not fully oriented on work achievement and DP 3 as an instrument of assessment has not been effective enough, so the mutation and promotion still occasionally defined by relationships are personal between subordinates and superiors. Training and education institutions activity still at domination by the structural position while training for the training of technical and functional office has not got the attention of proportionately.

Renewal of the Culture in encouraging bureaucracy to be more efficient, professional, and transparent.The reality of organizational culture shows that there is still a culture that is not conducive to some employees such as discipline and work ethos that have not been optimal, the culture of followership which is less rational and based on vested (expect to benefit) upward orientation is more advanced than customer orientation. Renewal of the institutional changes made through the structure, formation, and eselonering based on the guidelines of the Central Government. Internally the structure of oragnisasi each of the units has been said to be slim due to the levels of the hierarchy (the chain of command) and span of control that still ideal, but the large amount of service (service 48) still allows for streamlined through mergers to service-the service has an affinity in task and function.

From the three variables (culture, structure, human resource development/bureaucrats) then the variable culture or organizational culture has a strong influence of efforts to build the public bureaucracy. Above all it turned out to be a human being is the most decisive factor in performing the renewal of the bureaucracy, because of improvements to culture, structure.

\section{ACKNOWLEDGMENT}

The researcher expresses the gratitude to Universitas Muhammadiyah Sidoarjo.

\section{REFERENCES}

[1] H.S. Edgar. Organizatioanl,Culture and Leadership, (1992)

[2] E.O. Hughes. Public Management snd Administration, 1994.

[3] S. Robbins. Perilaku Organisasi, Konsep, Kontroversi dan Aplikasi (terjemahan), Prenhalindo, Jakarta, 1996.

[4] P. Wright, J. Kroll, P. Parnell, John, Strategic Management Concept and Cases, New Jersey, 1996.

[5] A.P. Bartel. Productivity gains from the implementation of employee training programs. Industrial relations: a journal of economy and society, 1994, 33(4), 411-425.

[6] A. C. Dulles. Centesimus annus and the Renewal of Culture. Journal of Markets and Morality, 1999, 2(1). 